\title{
The Impact of Management Factors on the Success and Failure of Health Information Systems
}

\author{
Khalil Kimiafar ${ }^{1}$, Masoumeh Sarbaz ${ }^{1}$, Abbas Sheikhtaheri² and Amirabbas Azizi ${ }^{3,4^{*}}$ \\ 'Department of Medical Records and Health Information Technology, School of Paramedical Sciences, \\ Mashhad University of Medical Sciences, Mashhad, Iran \\ 2Department of Health Information Management, School of Health Management and Information Sciences, \\ Iran University of Medical Sciences, Tehran, Iran \\ ${ }^{3}$ Student Research Committee, Department of Medical Informatics, Faculty of Medicine, \\ Mashhad University of Medical Sciences, Mashhad, Iran; Aziziaa901@mums.ac.ir \\ ${ }^{4}$ Department of Health Information Technology, School of Allied Health Professions, \\ Ahvaz Jundishapur University of Medical Sciences, Ahvaz, Iran
}

\begin{abstract}
There are several factors that can influence the success and failure of health information systems including functional, technical, cultural, and economic factors, however one of the most important factors is the impact of management factors. This research aimed to evaluate the impact of management factors on the success and failure of health information systems in the current evidences and also provide a framework in this field. This applied study was conducted by the qualitative method. It also includes two different stages of reviewing the evidences and the implementation of the Delphi technique in order to validate the proposed model. The presented model in this study consists of 16 management factors affecting the success and the failure of health information systems. The sub-factors including user involvement, having strategy, accessibility, allocation and prioritization of the competitive resources were introduced as the most important management factors with $86.7 \%$ of "totally agree" comments due to the opinions of experts. In general the results indicated that the relationship between the management structure of health information systems and the successes and failures of these systems has been considered during the recent years. An open and multi-factorial viewpoint should be developed for the implementation of health information systems and also all factors affecting the success and failure of these systems should be considered.
\end{abstract}

Keywords: Failure, Health Information System (HIS), Management Factors, Success

\section{Introduction}

Since the information systems are seductive and there are increasing expectations of these systems, then it can causes the managers to deal with the problems in the selection and designing of information systems. The managers of organizations and the information systems managers should be able to design, conduct, and evaluate the projects of the information systems as well. In this regard, selecting or designing the systems in accordance with the organization's needs is mostly important ${ }^{1}$. Nowadays, it seems difficult to imagine a health care system without information technologies. It is clear that the use of new information technology has provided the significant opportunities in order to reduce medical errors, support the health care professionals, increase the efficiency of health care, and even improve the quality of patient care ${ }^{2}$.

If the managers fail in their investments for the health information technologies and cannot reach their expected results, then they are very surprised. Although

${ }^{*}$ Author for correspondence 
these failures seems surprising and accidental, but the fact is that a common cause of failure in the most information systems is the neglect of the delicate points and activities which have been conducted by different people and at the different periods ${ }^{3}$. Since the information system is complex and multi-dimensional, its failure and success may occur in the various conditions ${ }^{4}$. Nowadays, study of the success and failure of the information systems is significantly important due to the increased attention of organizations to the costs related to the projects of information systems and obtaining the minimum benefits arising from them. If the desired information system is not used enough, it is not applicable, or its utility is difficult and time-consuming, then the system will be failed ${ }^{1}$. The success of information systems means that system can obtain what it aimed to and also what is the aim of its development; it has been operational at the right time and with the pre-planned costs; the project team and members are satisfied with the results while they are continuously satisfied ${ }^{5}$.

So far, millions of dollars have been spent on the information systems projects which they have failed while more than million dollars have been lost after the implementation of these systems and due to their bad performance ${ }^{5}$. Despite the rigorous researches which are conducted in order to identify success factors of these systems, however implementation of Information Technology (IT) projects is often not associated with success ${ }^{6}$. In the industrial sector, at least $40 \%$ of IT projects fail to meet the business requirements ${ }^{6}$. Some evidences report the failure rate as $70 \%{ }^{6}$. Other studies demonstrate that only one-eighth of IT projects can be considered truly successful whereas more than half of them are not going forward according to the defined budget and schedule and they still do not provide the requirements ${ }^{6}$. The similar rates have been reported for the failure rate of information technologies in the health systems ${ }^{7,8}$. Among the health organizations, delay or cancel of software projects have been highly reported ${ }^{9}$. Over the years, several serious problems have frequently reported regarding the different areas of the Hospital Information System (HIS) and medical records ${ }^{10}$, ambulance service ${ }^{11,12}$, national, local and social health information network ${ }^{12}$, public health systems ${ }^{13,14}$, patient education ${ }^{15}$, and the physician's orders ${ }^{16-18}$ in many countries. These issues have a particular importance especially in the health care centers, where the human health is at stake. The poor development of these systems causes health care professionals to work with their computers instead of taking care of the patients at most of their times ${ }^{19}$.

Hospitals are the strongly information-oriented organizations and pay substantial sums of money for processing and management of the information ${ }^{20}$. Effectiveness and efficiency of the hospital staff depends on the quality of information systems which are used by organizations. Therefore decisions of the managers in relation to investment on the IT are very vital in the survival and development of the organizations ${ }^{21-23}$. The use of the information systems has changed the management of patient care in the hospitals significantly. However, although the integrated information systems of the hospitals lead to use the resources more efficient, but it did not result in significant increases in the effectiveness of the provided services, and improving the quality of health care and increasing the productivity in many countries ${ }^{2}$. The Number of the problems such as lack of the strategic planning, organizational problems, incompetence of the IT departments and bureaucracy has shown themselves in successful use of these systems much more than technical and financial obstacles $^{24}$.

Several factors influence the success and failure of health information systems such as functional, technical, cultural and economic factors ${ }^{25}$. For example: Maadanchian introduces the lack of efficiency and utility of software as one of the major problems for using them in his research. He also states the main reasons of these problems as follows ${ }^{26}$ :

- The lack of adequate knowledge of the system analysts and developers on the traditional systems of human resources.

- The lack of adequate knowledge of managers and users on the capabilities of software systems.

- The traditional approaches towards the development of the systems and the lack of a clear explanation on the requirements.

- The lack of necessary standards for introduction of the systems.

- The lack of appropriate culture for the use of resources.

Neamatbakhsh and colleagues state as: Nowadays, one of the most expensive investments of the industry and services departments is the investment in the information systems, which aims to improve the performance of organizations and individuals while certainly the success 
of this investment is necessary to be evaluated. However, access to objective criteria for evaluation of the success implementation of information systems is not so simple ${ }^{27}$. Habibi et al. concluded that the strategic, managerial and sociocultural factors are the more important in the failure of IT projects rather than the financial, economic, and human-technical factors. They also mentioned the lack of sufficient commitment of executives and their unfamiliarity of the people and officials with the structure and function as the main cause of failure in the IT projects. They believe that the failure rate of these projects increases along with the enlargement of the organization and project ${ }^{28}$.

In this regard, Geisler et al. in a research about the criteria used in order to evaluate the information system of US hospitals introduced the most important criteria due to the opinions of the experts as: $94 \%$ economic compensation, increased productivity by $86 \%, 84 \%$ patient satisfaction, reduction of the costs by $72 \%$, compliance of the validation requirements by $65 \%, 63 \%$ performance improvement, assistance to the organizational mission by $63 \%$, improvement of the provided services by $54 \%$, efficient use of human resources as $52 \%$, improvement of efficiency as $51 \%, 47 \%$ chance of competing, improvement of data accuracy by $31 \%$, and satisfaction of taxpayers by $25 \%{ }^{29}$. Heeks defines examples of failure in IT in his research as follows which should be added to the list of success and failure factors ${ }^{8}$ :

- An important issue is that Health Information Technology (HIT) projects have different aspects including IT, medical, and management instructions while it includes certain cultural values. Therefore, if the interest groups and developing teams are difference or have different levels of the recognition and acceptance, then failure occurs.

- The difference in the organizational and cultural conditions between private and public hospitals.

- Cultural differences between the industrial and developing countries and within these countries.

Larsen states the issues related to the success of the information system including technical issues, humanitarian issues, knowledge and management activities, the interaction between employees and IT experts, the strategic requirements, technical and operational, organizational elements, and perspectives. The framework he defined for the elements related to the innovation of the information system, is divided into five structures ${ }^{30}$. Larsen did not opine about which elements or structures have the more or less effects on the activities of the organization and which cases increase the successes. Freed states ten reasons for the failure of information systems in the hospital as follows ${ }^{3}$ : not reengineering, no "wow", automation not information, no structured systems development methodology, no user governance, not userfriendly, poor or no strategic alignment, no dedicated project resources, questionable data integrity and organizational and/or user instability.

According to the mentioned issues, the researchers of this study aimed to review the management factors affecting the success and failure of the health information systems in the published evidences and develop a model for that.

\section{Methodology}

This applied study was conducted by the qualitative methods. The different stages of research include reviewing the evidences and the implementation of the Delphi technique in order to validate the proposed model. At the stage of reviewing the evidences of the research population includes all the articles published about the management factors affecting the successes and failures of the health information systems that had been listed in the English or Persian languages at the databases including Ovid Medline, PubMed, Scopus, ScienceDirect, SID. Additionally, the lists of references in the relevant articles were also searched. Eventually in the present research, the key concepts were extracted from each study using a narrative synthesis; the extracted concepts were placed together and also were classified. So that the proposed framework was formed according to this classification and it was approved by the Delphi study and the use of experts' opinions in this context. Research population in the validation stage of the proposed model included scholars and experts of the subject. The following characteristics and the criteria were considered for the identification and selection of the research population:

Faculty members of the Health Information Management and Medical Informatics fields, who had $\mathrm{PhD}$ degree, at least five years of work experience and the education, research, or administrative records in the fields of the health information systems. At this stage 15 scholars and experts composed a panel group in order to 
check the validity of the proposed model. These people were selected using the purposive sampling method. The opinions of the researchers were investigated through questionnaires. This means that the questionnaire was prepared based on the content of the proposed model. The necessary data were collected through the distribution of questionnaires by emails and via regular post. The questionnaire included three parts of which part one contained the instructions for completing the questionnaire; the second part was the profile of completing person while the third part composed of the questions about the constituent elements of the proposed model. This part contained 16 questions related to the management factors.

Data was analyzed based on the descriptive statistics in the validation stage of the proposed model. Consensus on the dimensions of the proposed model and its constituent elements was obtained at the first stage of the Delphi study. Therefore the Delphi study was conducted through only one round in the present research. The responses were scored from one to five, this means that the completely disagree opinion had score one, agree had score two, somewhat agree scored as three, agree scored as four, and finally the score five was allocated to the complete agree option. The criterion for the considering various subjects in the final model were acceptance of them by $75 \%$ of the experts. The subjects which obtained less than 50\% approval were removed from the draft model. If a subject had the agreement of $50 \%$ to $75 \%$ of the experts, then it was surveyed in the next round of the Delphi technique (In this research none of the dimensions of the proposed model were required to be assessed in the second round). Given that the scale of the data measuring and also regarding to the asymmetric and compression of the data on the left hand (toward the higher scores) the median presented the centrality and distribution of data. Therefore, in the present research the median was reported. The following scale was used to judge the acceptance or rejection of the suggested items: (The maximum possible score for each item, was score five)

- The required scores in order to accept each item: the scores between 3.75 and 5 (scores 4 and 5).

- The required score for reviewing each item: Scores between 2.5 and 3.75 (Score: 3).

- The required score for rejection of each item: Scores less than 2.5 ( 1 and 2 scores).

\section{Results}

The key concepts about management factors for the success and failure of health information systems extracted from the reviewed evidences were classified in Table 1 and the frequency and percentage of each extracted concept and related sources were also reported.

Table 1. The management success factors and their frequency in selected studies

\begin{tabular}{|c|c|c|}
\hline Management Factors & $\mathrm{N}(\%)$ & References \\
\hline Managers commitment & $5(45.5)$ & $24,31-34$ \\
\hline $\begin{array}{l}\text { Formulation and expression of } \\
\text { a clear vision for the enterprise } \\
\text { showing the HIS as part of it }\end{array}$ & $1(9)$ & 32 \\
\hline $\begin{array}{l}\text { Setting clear goals and } \\
\text { instructions }\end{array}$ & $3(27.2)$ & $6,8,32$ \\
\hline Flexible planning & $3(27.2)$ & $32-34$ \\
\hline Prospective and proactive control & $1(9)$ & 33 \\
\hline $\begin{array}{l}\text { Change (goals, software and } \\
\text { plans) using Pilot study results }\end{array}$ & $2(18.1)$ & 32,33 \\
\hline $\begin{array}{l}\text { Coping with the impact of } \\
\text { change }\end{array}$ & $3(27.2)$ & $8,32,33$ \\
\hline Users involvement & $2(18.1)$ & 3,33 \\
\hline $\begin{array}{l}\text { Internal communication and } \\
\text { clear feedback }\end{array}$ & $3(27.2)$ & $32-34$ \\
\hline Having a strategy & $4(36.3)$ & $24,32-34$ \\
\hline $\begin{array}{l}\text { Handling the diversity within } \\
\text { stakeholder goals }\end{array}$ & $2(18.1)$ & 31,33 \\
\hline $\begin{array}{l}\text { Using formal project } \\
\text { management methodology }\end{array}$ & $2(18.1)$ & $(3,33)$ \\
\hline $\begin{array}{l}\text { Dedicate, availability and } \\
\text { prioritize of competitive hospital } \\
\text { resources (human, financial and } \\
\text { physical resources and time) }\end{array}$ & $7(63.3)$ & $\begin{array}{c}6,8,31 \\
32,34-36\end{array}$ \\
\hline $\begin{array}{l}\text { Identify and mitigate risk } \\
\text { (risk management) }\end{array}$ & $2(18.1)$ & 6,37 \\
\hline $\begin{array}{l}\text { Consider IT implementation } \\
\text { as a change process }\end{array}$ & $1(9)$ & 33 \\
\hline $\begin{array}{l}\text { Understanding socio-technical } \\
\text { nature of HISs }\end{array}$ & $3(27.2)$ & $6,21,38$ \\
\hline Management factors in general & $11(100)$ & $\begin{array}{c}3,6,8,21, \\
24,31-35,38\end{array}$ \\
\hline
\end{tabular}

Eventually the proposed model was formed based on these concepts and the classifications. In the following, the demographic data associated with the opinions 
of the experts participated in the Delphi study has been presented and then, findings about the validation of the suggested model is provided based on its axis. The age average of the participants in the Delphi study was 39.67 \pm 8.21 years while these people had work experience with an average of $13.3 \pm 8.12$ years. As it is demonstrated in Table 2, all of the participants had $\mathrm{PhD}$ degrees while most of them educated in the health information management. All the experts were the faculty member of a university.

Table 2. Demographic information of Delphi Participants

\begin{tabular}{|l|l|c|c|}
\hline \multicolumn{2}{|l|}{ Variable } & N & Percent \\
\hline \multirow{2}{*}{$\begin{array}{l}\text { Educational } \\
\text { Level }\end{array}$} & Ph.D. & 15 & 100 \\
\cline { 2 - 4 } Field & MSc & 0 & 0 \\
\hline \multirow{2}{*}{$\begin{array}{l}\text { Faculty } \\
\text { Member }\end{array}$} & $\begin{array}{l}\text { Health Information } \\
\text { Management }\end{array}$ & 9 & 60 \\
\cline { 2 - 4 } & Medical Informatics & 6 & 40 \\
\hline \multirow{3}{*}{ Job Place } & Yes & 15 & 100 \\
\cline { 2 - 4 } & No & 0 & 0 \\
\cline { 2 - 4 } & Faculty & 14 & 93.3 \\
\hline
\end{tabular}

Table 3 shows that the user involvement; having strategy; accessibility, allocation and prioritization of the resources were introduced as the most important factors among the other factors as $86.7 \%$ of the experts were completely agree with their effect. All suggested factors and sub-factors of successes and failures in the preliminary model were confirmed by the experts in the Delphi by obtaining the score higher than $75 \%$ and they were also included in the final model. The final model is depicted in Figure 1.

\section{Discussion}

The presented framework consisted of 16 management factors influencing success and failure of the health information systems. The results of reviewing the evidences revealed that the management factors have more importance compared to other factors in the success of such systems. A study on 214 projects conducted in 2007 on various sectors which included 18 projects in the health care section, introduced inadequate performance of management as $65 \%$ of the factors related to the failure of the projects. The remaining 35\% were classified in the technical factors group ${ }^{6}$.

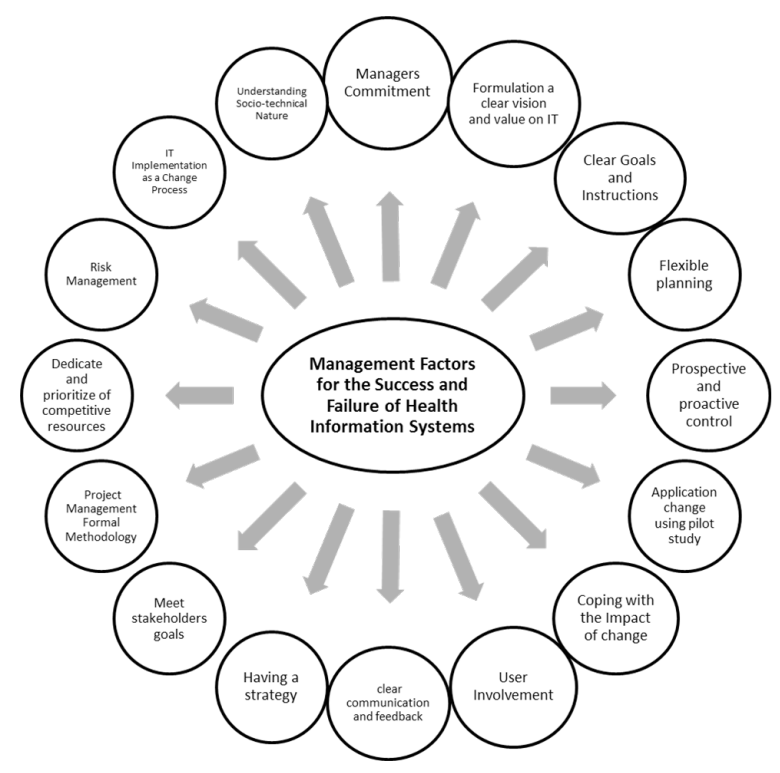

Figure 1. Final model of management factors for the success and failure of health information systems.

The strong support of management in order to identify the authority is very necessary. In two studies, the persons responsible for implementation of the information systems had not necessary authority to make decisions ${ }^{16,39}$ while the results demonstrated that the lack of communication between the organization structure and implementation strategy of the information system will complicate the process of implementation more. Most participants (80\%) in the present research were also agreed with placing the management commitment as a factor of success and failure in the final version of the model.

Another management sub-factor which was allocated $86.7 \%$ of the "complete agreed" comments was the factor of access to, allocation, and prioritization of the competitive resources in the hospital. Hanmer also emphasized on the importance of two factors including the access to the resources at the state level and accession and allocation of resources in the hospitals. He states that the limited number of available skilled personnel for supporting the implementation of computerized hospital information systems was identified as main concern in all studied hospitals and by all interviewees. Accession to medical sources for implementation, training, and maintenance of the computerized hospital information systems in the hospital level was considered as a factor in the Hanmer model. This factor demonstrated allocation of the hospital resources for the development of computerized 
Table 3. Participant's viewpoints about management factors

\begin{tabular}{|c|c|c|c|c|c|c|c|c|}
\hline \multirow[t]{2}{*}{$\begin{array}{l}\text { Management } \\
\text { Sub-factors }\end{array}$} & $\begin{array}{l}\text { com- } \\
\text { pletely } \\
\text { disagree }\end{array}$ & disagree & $\begin{array}{l}\text { somewhat } \\
\text { agree }\end{array}$ & agree & $\begin{array}{l}\text { completely } \\
\text { agree }\end{array}$ & \multirow[t]{2}{*}{ Median } & \multirow[t]{2}{*}{$\begin{array}{c}\text { Interquartile } \\
\text { (Q1,Q3) }\end{array}$} & \multirow[t]{2}{*}{$\begin{array}{c}\text { Final } \\
\text { agreement }\end{array}$} \\
\hline & N (\%) & N (\%) & N (\%) & $\mathrm{N}(\%)$ & N (\%) & & & \\
\hline Managers commitment & 0 & 0 & $\begin{array}{c}1 \\
(6.7)\end{array}$ & $\begin{array}{c}2 \\
(13.3)\end{array}$ & $\begin{array}{c}12 \\
(80.0)\end{array}$ & 5 & $(5,5)$ & Yes \\
\hline $\begin{array}{l}\text { Formulation and } \\
\text { expression of a clear vision } \\
\text { for the enterprise showing } \\
\text { the HIS as part of it }\end{array}$ & 0 & 0 & $\begin{array}{c}3 \\
(20.0)\end{array}$ & $\begin{array}{c}1 \\
(6.7)\end{array}$ & $\begin{array}{c}11 \\
(73.3)\end{array}$ & 5 & $(4,5)$ & Yes \\
\hline $\begin{array}{l}\text { Setting clear goals and } \\
\text { instructions }\end{array}$ & 0 & 0 & $\begin{array}{c}1 \\
(6.7)\end{array}$ & $\begin{array}{c}2 \\
(13.3)\end{array}$ & $\begin{array}{c}12 \\
(80.0)\end{array}$ & 5 & $(5,5)$ & Yes \\
\hline Flexible planning & 0 & 0 & $\begin{array}{c}2 \\
(13.3)\end{array}$ & $\begin{array}{c}2 \\
(13.3)\end{array}$ & $\begin{array}{c}11 \\
(73.3)\end{array}$ & 5 & $(4,5)$ & Yes \\
\hline $\begin{array}{l}\text { Prospective and proactive } \\
\text { control }\end{array}$ & 0 & 0 & $\begin{array}{c}2 \\
(13.3)\end{array}$ & $\begin{array}{c}4 \\
(26.7)\end{array}$ & $\begin{array}{c}9 \\
(60.0)\end{array}$ & 5 & $(4,5)$ & Yes \\
\hline $\begin{array}{l}\text { Change (goals, application } \\
\text { and plans) using pilot } \\
\text { study results }\end{array}$ & 0 & 0 & $\begin{array}{c}2 \\
(13.3)\end{array}$ & $\begin{array}{c}3 \\
(20.0)\end{array}$ & $\begin{array}{c}10 \\
(66.7)\end{array}$ & 5 & $(4,5)$ & Yes \\
\hline $\begin{array}{l}\text { Coping with the impact } \\
\text { of change }\end{array}$ & 0 & 0 & $\begin{array}{c}2 \\
(13.3) \\
\end{array}$ & $\begin{array}{c}3 \\
(20.0)\end{array}$ & $\begin{array}{c}10 \\
(66.7)\end{array}$ & 5 & $(4,5)$ & Yes \\
\hline User involvement & 0 & 0 & $\begin{array}{c}2 \\
(13.3)\end{array}$ & 0 & $\begin{array}{c}13 \\
(86.7)\end{array}$ & 5 & $(5,5)$ & Yes \\
\hline $\begin{array}{l}\text { Internal communication } \\
\text { and clear feedback }\end{array}$ & 0 & $\begin{array}{c}1 \\
(6.7)\end{array}$ & $\begin{array}{c}2 \\
(13.3) \\
\end{array}$ & $\begin{array}{c}1 \\
(6.7)\end{array}$ & $\begin{array}{c}11 \\
(73.3) \\
\end{array}$ & 5 & $(4,5)$ & Yes \\
\hline Having a strategy & 0 & 0 & 0 & $\begin{array}{c}2 \\
(13.3) \\
\end{array}$ & $\begin{array}{c}13 \\
(86.7)\end{array}$ & 5 & $(5,5)$ & Yes \\
\hline $\begin{array}{l}\text { Handling the diversity } \\
\text { within stakeholder goals }\end{array}$ & 0 & 0 & $\begin{array}{c}3 \\
(20.0) \\
\end{array}$ & $\begin{array}{c}1 \\
(6.7)\end{array}$ & $\begin{array}{c}11 \\
(73.3) \\
\end{array}$ & 5 & $(4,5)$ & Yes \\
\hline $\begin{array}{l}\text { Using formal project } \\
\text { management } \\
\text { methodology }\end{array}$ & 0 & 0 & $\begin{array}{c}2 \\
(13.3)\end{array}$ & $\begin{array}{c}3 \\
(20.0)\end{array}$ & $\begin{array}{c}10 \\
(66.7)\end{array}$ & 5 & $(4,5)$ & Yes \\
\hline $\begin{array}{l}\text { Dedicate, availability and } \\
\text { prioritize of competitive } \\
\text { hospital resources (human, } \\
\text { financial and physical } \\
\text { resources and time) }\end{array}$ & 0 & 0 & $\begin{array}{c}1 \\
(6.7)\end{array}$ & $\begin{array}{c}1 \\
(6.7)\end{array}$ & $\begin{array}{c}13 \\
(86.7)\end{array}$ & 5 & $(5,5)$ & Yes \\
\hline $\begin{array}{l}\text { Identify and mitigate } \\
\text { risk (risk management) }\end{array}$ & 0 & 0 & $\begin{array}{c}1 \\
(6.7)\end{array}$ & $\begin{array}{c}3 \\
(20.0) \\
\end{array}$ & $\begin{array}{c}11 \\
(73.3)\end{array}$ & 5 & $(4,5)$ & Yes \\
\hline $\begin{array}{l}\text { Consider IT implementation } \\
\text { as a change process }\end{array}$ & 0 & 0 & $\begin{array}{c}1 \\
(6.7)\end{array}$ & $\begin{array}{c}2 \\
(13.3)\end{array}$ & $\begin{array}{c}12 \\
(80.0)\end{array}$ & 5 & $(5,5)$ & Yes \\
\hline $\begin{array}{l}\text { Understanding } \\
\text { socio-technical nature } \\
\text { of HISs }\end{array}$ & 0 & 0 & $\begin{array}{c}1 \\
(6.7)\end{array}$ & $\begin{array}{c}2 \\
(13.3)\end{array}$ & $\begin{array}{c}12 \\
(80.0)\end{array}$ & 5 & $(5,5)$ & Yes \\
\hline
\end{tabular}


hospital information systems in hospitals as a reflection of management's commitment for ensuring usefulness and the continued use of computerized hospital information systems in the hospitals. The following practical suggestions have been presented in order to cope with resource constraints for implementation of the computerized hospital information systems and also based on the results of this research ${ }^{32}$ :

- Management and end users should have an appropriate understanding towards the functionality of the computerized hospital information systems in order to be able to use its available functions effectively. In all studied hospitals, the members of management team expressed their concerns related to their limited understanding from the computerized hospital information systems and the lack of opportunity in order to improve their understanding of these systems.

- The management commitment to continuous provision of the resources for implementation of the computerized hospital information systems and also particularly trying to ensure the quality and consistency of data, are the key factors in order to ensure the effective use of these systems in the hospital.

- Appropriate agreed contracts and service levels are essential in order to provide hospital requirements for implementation of the computerized hospital information systems.

There are various types of a contingency model however organizational systems, information system, management system, and the environment should be aliened. The diversity is observed in the environmental factor or factors among the literatures of the information systems. Generally the systems should be proportional with environmental factors. Additionally another important factor is the alignment between the technology and the user tasks that should be consid$\operatorname{ered}^{40}$. Another important issue is also the alignment between the information system and the organizational strategy. Health information system should be exactly compatible with its environment and it also should be able to change the conditions. However the main goal of HISs is developing and supporting the organizational changes with the aim of improving the performance of health care organizations. On the other hand, if a health information system makes a lot of changes, then it encounter with the fail risks and it is clear that the more changes means the more risks. For example the fail of information systems in the London ambulance service was based on the speed and the deep of changes $^{8}$. In the present study also 11 (73.3\%) of participants were completely agreed with the factor of risk management as the management sub-factor in the proposed model.

Since only the factors were identified in the current research, then it is suggested to conduct a research on the prioritization of the management factors affecting the success and the failure of HIS. Additionally, in this study, there were some factors among the extracted factors which they could be integrated with other different groups or also some factors may be separated to the more detailed factors. Therefore the most appropriate group should be carefully selected for each factor.

\section{Conclusion}

In summary, the results indicate that the management factors related to HISs has been considered in connection with the successes and failures of these systems in recent years. Therefore these factors should be considered in planning of such systems for implementation and the managers should also receive the required trainings. Implementation of the HIS is depending on an open and multi-factor viewpoint and all factors affecting the success and failure of these systems should be regarded.

\section{References}

1. Sadoughi F, Sheikhtaheri A, Meydani Z, Shahmoradi L. Management Information System. Tehran: Jafari. 2010.

2. Kimiafar K, Sadoughi F, Sheikhtaheri A, Sarbaz M. Prioritizing factors influencing nurses' satisfaction with hospital information systems: A fuzzy analytic hierarchy process approach. Computers Informatics Nursing. 2014; 32(4):174-81.

3. Freed DH. Certain death: Ten predictors of hospital information system failure. Health Care Manag. 2006; 25(1): 26.

4. John W. How can IS/IT projects be measured for success? Int J Proj Manag. 1998; 16(1):59-63.

5. Fortune J, Peters G. Information systems: Achieving success by avoiding failure. Chichester, England: John Wiley and Sons. 2005. 
6. Kaplan B, Harris-Salamone KD. Health IT success and failure: Recommendations from literature and an AMIA workshop. J Am Med Informat Assoc. 2009; 16(3):291-9.

7. Wears R, Berg M. Computer technology and clinical work: Still waiting for godot. JAMA. 2005; 293(10):1261-3.

8. Heeks R. Health information systems: Failure, success and improvisation. Int J Med Informat. 2006; 75(2):125-37.

9. Jones C. Patterns of large software systems: Failure and success. Computer. 1995; 28(37-86).

10. Brown AD, Jones MR. Doomed to failure: Narratives of inevitability and conspiracy in a failed IS project. Organization Studies. 1998; 19(1):73-88.

11. Beynon-Davies P. Information systems failure: The case of the London Ambulance Service's Computer Aided Despatch project. Eur J Inf Syst. 1995; 4(3):171-84.

12. Beynon-Davies P, Lloyd-Williams M. When health information systems fail. Top Health Inform Manag. 1999; 20(1):66-79.

13. Southon FCG, Sauer C, Dampney CNG. Information technology in complex health services: Organizational impediments to successful technology transfer and diffusion. J Am Med Informat Assoc. 1997; 4(2):112-24.

14. Wells S, Bullen C. A near miss: The importance of context in a public health informatics project in a new zealand case study. J Am Med Informat Assoc. 2008; 15(5):701-4.

15. van't Riet A, Berg M, Hiddema F, Sol K. Meeting patients' needs with patient information systems: Potential benefits of qualitative research methods. Int J Med Informat. 2001; 64(1):1-14.

16. Massaro TA. Introducing physician order entry at a major academic medical center: I. Impact on organizational culture and behavior. Acad Med. 1993; 68(1):5-20.

17. Aarts J, Doorewaard H, Berg M. Understanding implementation: The case of a computerized physician order entry system in a Large Dutch University Medical Center. J Am Med Informat Assoc. 2004; 11(3):207-16.

18. Aarts J, Berg M. SameSystems, DifferentOutcomes. Methods Inf Med. 2006; 45:53-61.

19. Rigby M. Evaluation - the Cinderella science of ICT in health. Methods Inf Med. 2006; 45:S114-S20.

20. Degoulet P, Fieschi M. Introduction to clinical informatics. New York: Springer-Verlag. 1996.

21. Aggelidis VP, Chatzoglou PD. Methods for evaluating hospital information systems: A literature review. Euro Med Journal of Business. 2008; 3(1):99-118.

22. Bates DW, Cohen M, Leape LL, Overhage JM, Shabot MM, Sheridan T. Reducing the frequency of errors in medicine using information technology. J Am Med Informat Assoc. 2001; 8(4):299-308.

23. Vafaee A, Vahedian M, Esmaeily H, Kimiafar K. Views of users towards the quality of hospital information system in training hospitals. J Res Health Sci. 2010; 10(1):47-53.
24. Zikos D, Mitsios A, Mantas J. Assessment of hospital information systems implementation: A case study. Studies in health technology and informatics. 2011; 165:123-8.

25. Sadoughi F, Kimiafar K, Ahmadi M, Shakeri MT. Determining of factors influencing the success and failure of hospital information system and their evaluation methods: A systematic review. Iran Red Crescent Med J. 2013; 15(12):e11716.

26. Madanchian A. Evaluation of human resource management software and its evaluation criteria [MSc thesis]. Tehran: Tehran University.1998.

27. Nematbakhsh M, Jamshidian M, Harandi F. Evaluation of success of management information system in industerial organization in Esfehan. 2001.

28. Habibi J, Akhavan M, Alimohammadloo M. A study on causes of failure of information technology projects and solution for prevention. Scound International Conference of Information Technology and Knowledge.Tehran: Amirkabir University. 2004.

29. Geisler E, Heller O. Management of medical technology: Theory, practice, and cases. Springer. 1997.

30. Larsen TJ. Information systems innovation: A framework for research and practice. Hershey, PA: Idea Group Publishing. 1998.

31. Pare G, Sicotte C, Jaana M, Girouard D. Prioritizing the risk factors influencing the success of clinical information system projects. A Delphi study in Canada. Meth Inform Med. 2008; 47(3):251-9.

32. Peute LW, Aarts J, Bakker PJM, Jaspers MWM. Anatomy of a failure: A sociotechnical evaluation of a laboratory physician order entry system implementation. Int J Med Informat. 2010; 79(4):e58-70.

33. Brender J, Ammenwerth E, Nykanen P, Talmon J. Factors influencing success and failure of health informatics systems. A Pilot Delphi Study. Methods Inf Med. 2006; 45:125-36.

34. Yusof MM, Kuljis J, Papazafeiropoulou A, Stergioulas LK. An evaluation framework for Health Information Systems: Human, organization and technology-fit factors (HOT-fit). Int J Med Informat. 2008; 77(6):386-98.

35. Hanmer LA, Roode JD, Isaacs S. Modelling the effect of limited or vulnerable resources on the use of computerised hospital information systems (CHISs) in South Africa. Studies in Health Technology and Informatics. 2007; 130:299-309.

36. Ahmadi M, Shahmoradi L, Barabadi M, Hoseini F. Usability evaluation of health information syetem. Health Administration Journal. 2011; 14 (44):11-21.

37. Sadoughi F, Aminpour F. A review on evaluation methods of health information systems. Iranian Journal of Medical Education. 2010; 10(5):1077-86. 
38. Rahimi B, Vimarlund V. Methods to evaluate health information systems in healthcare settings: A literature review. J Med Syst. 2007; 31(5):397-432.

39. Southon G, Sauer C, Dampney K. Lessons from a failed information systems initiative: Issues for complex organisations. Int J Med Informat. 1999; 55(1):33-46.
40. Sheikhtaheri A, Kimiafar K, Sarbaz M. Evaluation of system quality of hospital information system: A case study on nurses' experiences. Studies in health technology and informatics. 2014; 205:960. 